\title{
Effect of sequence control sprays on cotton bollworms and side effect on some sucking pests and their associated predators in cotton fields.
}

\author{
Al-Shannaf, H. M. H. \\ Plant Protection Research Institute, Agric. Res. Center, Dokki, Giza, Egypt
}

\section{ABSTRACT}

Field evaluation of sequence control sprays were carried out at AbouHamad district, Sharkia Governorate, Egypt in the two successive cotton growing seasons 2008 and 2009 against cotton bollworms, Pectinophora gossypiella (Sound.), Earias insulana (Boisd.) and Heliothis armigera (Hüb.) infesting cotton green bolls as well as some sucking pests and some important predators. The seasonal average reductions in cotton bollworms infestation attained 66.67 and $61.18 \%$ in 2008 and 2009 seasons.

Conventional insecticides mixture IGRs treatments attained 91.82 and $84.42 \%$ in 2008 season of Nezara viridula and Tetranychus spp.; 90.13 and $75.38 \%$ of $N$. veridula and Aphids in 2009 season, respectively. The lowest mean numbers of insects were 0.78 and 1.48 insects/week of Tetranychus spp. and $N$. viridula in 2008; 0.41 and 3.33 individuals/week in 2009 season in treatments of true spiders and $N$. viridula compared with untreated plots recorded 0.96 and 1.48 in 2008 season of true spiders and $N$. viridula, while in 2009 the lowest mean numbers were 1.26 and 7.93 individuals/week of Tetranychus spp. and $N$. viridula. The tested programs resulted in the highest degree of $\%$ reduction for all investigated predators except for Chrysoperla carnea attained $99.54,94.05$ and $91.89 \%$ of Peaderus alfierii, Coccinella spp. and Scymnus spp. in 2008.In 2009 seasons the highest reduction were 100.00, and $84.30 \%$ of Coccinella spp. and Scymnus spp.

The insect predators (Chrysoperla carnea, Coccinella spp. Orious spp., Peaderus alfierii, Scymnus spp., and true spiders) were influence significant and insignificant relationship in the two seasons and ranged between positive \& negative relationship. On the other hand, results indicate that the all predators affect sucking pests with $29.73,32.54 ; 35.57,83.22 ; 61.88,83.54 ; 49.14,46.26$ and $52.46,58.26 \%$ mutable regression values of Aphis gossypii, B. tabaci, Emboasca lybica, N. viridula and Tetranychus spp. during 2008 and 2009, respectively.

\section{INTRODUCTION}

Cotton, Gossypium barbadence L. is one of the most important economical crops in Egypt and allover the world where it is employed in several industrial productions i.e. ginning, textile, Food oil, soap, furniture and many other industries, as well as a source of foreign coin when exported to another countries. Cotton bollworms are the most destructive pests infesting cotton plants. The pink bollworm (PBW), Pectinophora gossypiella (Saunders) (Lepidoptera: Gelechiidae) is the key pest of cotton, (Gossypium spp.) in many cotton producing areas of the world. Continuing economic losses, social and environmental concerns. In Egypt, Cotton plants are usually subjected to be attacked by numerous insect pests and or Egyptian conditions during all different stages of their growth are the aphid, Aphis gossypii 
Glover; the whitefly, Bemesia tabaci (Genn.); the cotton leafhopper, Empoasca lybica (deBerg;) the cotton thrips, Thrips tabaci (lind.); the Egyptian cotton Leafworm, Spodoptera littoralis (Boisd.); the spiny bollworm, Earias insulana Boisd.; the pink bollworm, Pectinophora gossypiella (Saund.) and the common red spider mite, Tetranychus spp.; Al-Shannaf (2002). The most serious pests are pink bollworm, Pectinophora gossypiella (Saunders) and the spiny bollworm, Earias insulana (Boisd.) which are considered destructive pests infesting cotton plants and causing usually severe damage resulting in high loss in both quantity and quality of the obtained yield. (Knight 2000) stated that the effect of individual insecticides as well as their combined action on major cotton pests and certain insect predators. However, any information on the interaction of insecticide mixtures on major pests is indispensable in cases of pest outbreaks. Also, insecticidal mixtures might play an important role in IPM systems where more than one pest are involved in plant infestation. IGRs are claimed to be safer for beneficial organisms than conventional insecticides, and they have been successfully used in IPM programs against many tree and small fruit pests.

The benzoylurea, chlorfluazuron (Atabron) and hexaflumuron (Consult) as insect growth regulators (IGRs) were studied in cotton fields and stated that chlorfluazuron is highly selective against lepidopterous larvae (Hegab, 2008). Alternative of conventional insecticides with biorational compounds are currently being investigated and included the used that are compatible with integrated pest management (Horowitz and Ishaaya 2004).

The aim of this study were carried out to evaluate the effectiveness of sequence insecticides mixtures with Insect growth regulators IGRs against cotton bollworms, (pink, spiny and american bollworms) infesting cotton green bolls and side effect on some major of cotton pests such as, (Aphis gossypii, Bemisia tabaci, Empoasca lybica, Thrip tabaci, Tetranychus spp. and Nezara viridula) and side effect on some important predators in cotton fields.

\section{MATERIALS AND METHODS}

\section{Effect of control programs against cotton bollworms}

Field experiments were carried out at Abou-Hamad distreict, Sharkia Governorate, Egypt, during two consecutive cotton growing seasons of 2008 and 2009. The experimental area was cultivated with the Egyptian cotton variety, Giza 86 sown after clover at $15^{\text {th }}$ and $27^{\text {th }}$ March during the two seasons, respectively in order to carry out control studies on the pink bollworm, P. gossypiella (Saund.), the spiny bollworm, E. insulana (Boisd.) and american bollworm, H. armigera (Hub.) attacking cotton plants and side effect on some sucking pests Aphis gossypii, Bemisia tabaci, Empoasca lybica, Tetranychus spp. and Nezara viridula) and their associated predators. The cotton areas were subjected to normal agricultural practices allover study periods and the following studies were conducted:

\section{Sequence control against cotton bollworms:}

\subsection{Experimental design:}

An area of about one feddan of cotton was subjected to each treatment of sequence insecticides. The experimental area of each treatment was divided into one treatment and control during 2008 and 2009 seasons; respectively each was divided to four replicates. Four sprays were applied at two week intervals for Profenofos, (Curacron) / mixture atabron (1st spray ; three weeks intervals were applied for pyrethroid, S-fenvalerate (Sumi-alfa) $5 \%$ EC. $2^{\text {nd }}$ spray $; 3^{\text {rd }}$ spray Chlorpyrifos 
methyl, (Dursban) / mixture atabron and $4^{\text {th }}$ spray Chlorpyrifos methyl, (Dursban) / mixture consult during 2008 and 2009 seasons. Spray program begin on $1^{\text {st }}$ and $15^{\text {th }}$ July, $5^{\text {th }}$ and August. in 2008 season, respectively., spray program begin on 10th ,26th July, $16^{\text {th }}$ August and $1^{\text {st }}$ Sept., respect. In 2009. Field spray applied by using dorsal solo motor, 20 litter in capacity and started at 3\% infestation of green cotton bolls.

\subsection{Sampling techniques:}

Weekly samples of 100 cotton bolls were collected just before and after the treatment and control treatments and were externally and internally inspected. The number of larvae in green cotton bolls were calculated to compare the efficiency of tested control agents against pink, spiny and American bollworms using, Henderson and Tilton equation (1955).

2. Insecticides:

2.1. Synthetic pyrethroids, S-fenvalerate, (Sumi-alfa EC 5\%) used at rate of 600 $\mathrm{ml} /$ feddan

2. 2. Organo-phosphorous compounds:

-Profenofos, (Curacron EC 72\%), at rate of $750 \mathrm{ml} /$ feddan

-Chlorpyrifos methyl, (Dursban EC 48\%), at rate of $1000 \mathrm{ml} /$ feddan.

2.3. Insect growth regulators (IGR's) compounds

- benzoylurea, Chlorfluazuron (Atabron $5 \%$ EC) used at rate of $400 \mathrm{ml} / \mathrm{feddan}$.

-benzoylurea, Hexaflumuron (Consult $10 \%$ EC) used at rate of $200 \mathrm{ml} /$ feddan.

3. Side effect of conventional insecticides /IGRs mixtures against major cotton pests populations on cotton fields

\subsection{Experimental design:}

The harmful effect of the tested compounds against some cotton pests was investigated. The numbers of pests Aphis gossypii, Bemisia tabaci, Empoasca lybica, Tetranychus spp. and Nezara viridula), were counted on 25 cotton plant, the insect were counted on three levels from three replicates of each treatment (100 cotton plant/treatment and control), before and weekly after insecticide applications. Weekly samples of cotton plant were started from $23^{\text {th }}$ of April until $15^{\text {th }}$ of September in 2008 season, from $29^{\text {th }}$ of April until $15^{\text {th }}$ of September in 2009 season. The reduction in number of sucking pests and predator's population were calculated using, Henderson and Tilton equation (1955).

\section{4- Side effect of conventional insecticides /IGRs mixtures against non target predators populations on cotton fields:}

The harmful effect of the tested compounds against some predators aphid lion, Chrysoperla carnea; beetles, Coccinella spp.; anthocoride bugs Orious spp.; staphylinid beetle. Peaderus alfierii; Scymnus spp. and True spiders were counted on three cotton levels (top, middle and bottom/plant). Twenty five cotton plants for every replicate, before and weekly after insecticide applications. The mean weekly numbers for each predator were recorded and the reduction percentage were estimated according to Henerson and Tileton equation (1955).

\section{RESULTS AND DISCUSSIONS}

\section{Effect of control programs against cotton bollworms:}

Data in Table (1) showed that boll larval numbers were influenced by tested programs in comparable with untreated cotton area. The reduction percentages in the boll infestation due to the tested programs were different. The highest average of reduction percentages were recorded $(81.98$ and $80.77 \%)$ after the $3^{\text {rd }}$ and $2^{\text {nd }}$ spray application, while the median reduction percentages were recorded after $4^{\text {th }}$ and $1^{\text {st }}$ 
spray of application (53.60 and $50.39 \%$ ) during 2008 season. In 2009, the highest average of reduction percentages were $(80.00$ and $64.08 \%)$ after the $2^{\text {nd }}$ and $3^{\text {rd }}$ weeks of application for $2^{\text {nd }}$ and $3^{\text {rd }}$ spray of applications, resp., while the lowest mean of reduction were recorded $(59.17$ and $41.46 \%)$ of the $1^{\text {st }}$ and $4^{\text {th }}$ spray of application. These data clear that $2^{\text {nd }}$ and $3^{\text {rd }}$ sprays is the best program achieved the highest reductions through the two cotton seasons followed by $4^{\text {th }}$ spray in 2008 and $1^{\text {st }}$ spray in 2009. Results cleared that all the tested control sprays caused highly decreasing in cotton bollworms larvae compared with untreated area. Seasonal mean numbers were (5.78 and 9.11) in the two seasons compared with in untreated plots (42.33 and 40.78). The seasonal reduction in cotton bollworms larvae were (66.67 and $61.18 \%)$ in the two seasons of study, respectively.

Results are agree with the authors in all the worlds such as Sidhu, et al. 1986; Watson, et al. 1986; Sarag and Satpute, 1988 and Dhawan, et al. 1990 reported that the conventional insecticides were the most effective reduction percentage of the cotton bollworms resulted in increased high yield of cotton seeds. Abdalla (1991) stated that the effects of chemical control programs on the rate of infestation of cotton bolls by the two bollworms, Pectinophora gossypiella and Earias insulana in Egypt. The obtained results revealed that three or four sprays through the season caused a satisfactory decrease of infestation and loss of yield. Simwat and Dhawan (1992) assessed the efficacies of conventional insecticides were the most compounds potent against cotton bollworms, while diflubenzuron alone and in combination with insecticides sequence reduced pest incidence and increased yield, although diflubenzuron was less effective than the other insecticides. Khattak et al. (2004) evaluated the effects of seven insecticides on cotton bollworms, and on the beneficial fauna on cotton. All the insecticides at their recommended rates were more effective on bollworms than untreated plots. Hegab (2008) stated that, all tested control programs influenced the boll infestation percentages compared with untreated cotton areas. high reduction of larval numbers in green cotton bolls was recorded (74.33, $73.58,63.72,59.70$ and $54.87 \%$ ) at insecticides only, insecticides then Trichogramma, Dipel 2x then insect ides, Dipel 2x only and T. evanescense only during three cotton seasons. Yousif-Kalil et al. (2008) found that relative effectiveness of spinosad and methoxyfenozide compared with chlorpyrifos against the pink bollworm $P$. gossypiella. The seasonal average reductions in pink bollworm attained 86.90, 81.93 and $63.62 \%$ in 2004 season; 84.79, 82.19 and $57.76 \%$ in 2005 season.

Table 1: Effect of tested controlling programs on the larval number of cotton bollworms and reduction percentages during 2008 and 2009 seasons.

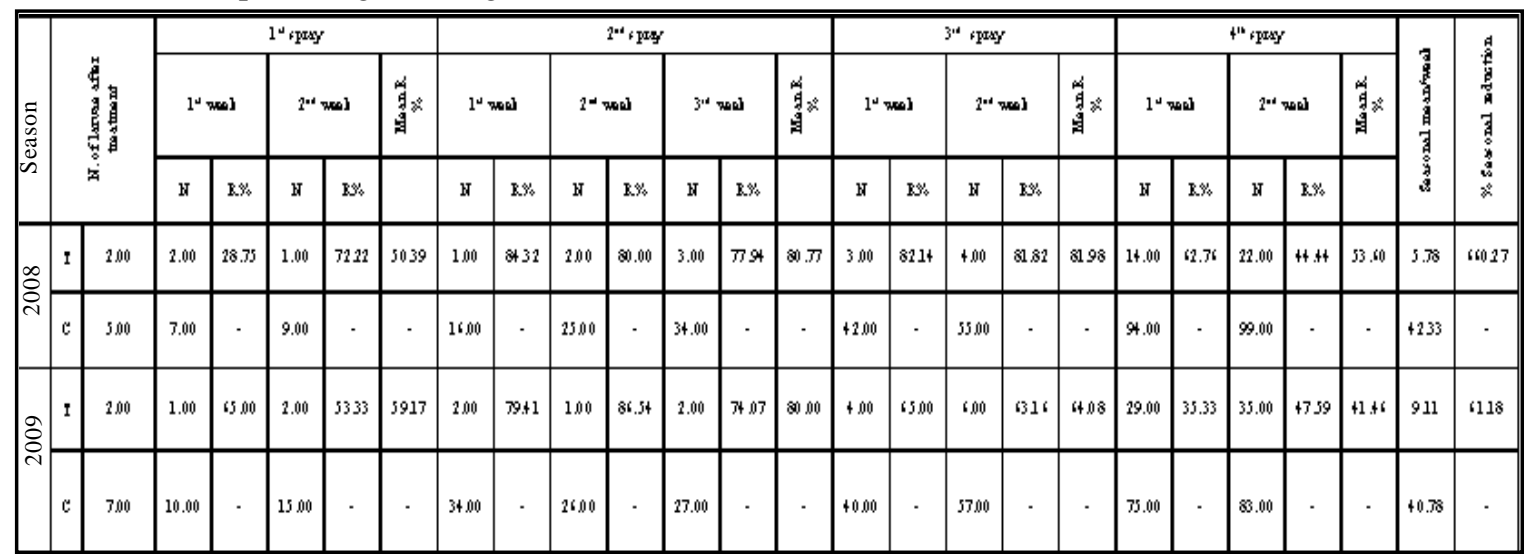

$\mathrm{T} .=$ treatment

$\mathrm{C}=$ Control

R.= Reduction $\%$

N. =Number of larvae 


\section{Side effect of conventional insecticides /IGRs mixtures against major cotton pests populations on cotton fields. -Aphis gossypii:}

Results in Tables (2 and 3) indicated that A. gossypii were influenced by the tested control programs. The highest mean of reduction percentages were recorded $(100.00,87.79$ and $83.89 \%)$ of the $2^{\text {nd }}, 1^{\text {st }}$ and $3^{\text {rd }}$ spray program in the first season. While in the second one the highest mean of reduction percentages were recorded $(100.00,100.00,62.79 \%)$ in the $1^{\text {st }}, 2^{\text {nd }}$ and $3^{\text {rd }}$ spray, but the least mean of reduction percentages was recorded $(38.71 \%)$ of the $4^{\text {th }}$ spray program, Meanwhile the average seasonal mean numbers of aphid population were 2.78 and 32.85 in the two seasons, respectively. But the seasonal reduction percentages were recorded (78.95 and $75.38 \%$ ) in the $1^{\text {st }}$ and $2^{\text {nd }}$ seasons.

Generally, from the test spray programs, results revealed that the pest tested sprays were $1^{\text {st }}, 2^{\text {nd }}$ and $3^{\text {rd }}$ in the two seasons, respectively. Compare with 15.37 and 33.44 in untreated area in the two seasons, respectively.

\section{-Bemicia tabaci:}

As shown in Tables (2 and 3) results cleared that the all tested programs caused highly decreased $B$. tabaci.The highest mean of reduction percentages were recorded $(85.48$ and $64.02 \%)$ of the $1^{\text {st }}$ and $3^{\text {rd }}$ spray programs, while the lowest reduction percentage were 32.74 and 45.89 of the $3^{\text {rd }}$ and $4^{\text {th }}$ sprays in 2008 season, but in the second season the highest mean of reduction percentages were recorded $(54.72 \%)$ of the $1^{\text {st }}$ spray program, while the lowest mean of reduction percentages were recorded $(28.38 \%)$ of the $4^{\text {th }}$ spray program in the $1^{\text {st }}$ season. In 2009 season the least mean reduction were recorded $28.38 \%$ of the $4^{\text {th }}$ spray . Seasonal average of reduction percentages were recorded (57.03 and $42.19 \%)$ in the 1st and 2nd seasons, respectively On the other hand the seasonal average numbers of $B$. tabaci were recoded (16.96 and 27.19 individuals) in untreated area in the two seasons, respectively.

Results are accordance with author in all the worlds such as Ishaaya et al. (2002) found that Emamectin is a macrocyclic lactone insecticide with low toxicity to non-target organisms and the environment, and is considered an important component in pestmanagement programmes for controlling field crop pests. Emamectin exhibits a considerable activity on the whitefly Bemisia tabaci (Gennadius). Otoidobiga, et al. (2003) found that Bemisia tabaci was susceptibilite to the insecticides currently sprayed on cotton. Naranjo and Akey (2005) stated that acetamiprid used for the control of Bemisia tabaci (Gen.) in cotton compared with a proven selective regime based on the insect growth regulators (IGRs) pyriproxyfen and buprofezin. Acetamiprid was highly effective in controlling all stages of $B$. tabaci compared with an untreated control, and generally produced lower pest densities than the IGR regime. Acetamiprid depressed populations of fewer predator taxa; but, for eight predator taxa significantly affected by both regimes, the average population reduction was roughly equal. In contrast, only four taxa were significantly reduced in the IGR regime compared with the untreated control and three of these were omnivores that function primarily as plant pests. Because of its, acetamiprid may play an important role in later stages of $B$. tabaci control where less emphasis is placed on selectivity. However, our results suggest that acetamiprid would be a poor substitute for the currently used IGRs in the initial stage of control where insecticide selectivity is crucial to a functional integrated control program for B. tabaci in cotton.

\section{-Empoasca lybicia}

Data in Tables (2 and 3) cleared that the reduction percentages in Jassid insect were different. The reduction percentages in this pest due to the tested programs were different: The highest mean of reduction percentages were recorded (84.86 and 60.17 
$\%$ ) of the $2^{\text {nd }}$ and $3^{\text {rd }}$ spray in 2008 season. While the lowest mean of reduction percentages were recorded $(46.40 \%)$ of the $4^{\text {th }}$ spray program. In 2009 season, the highest mean of reduction percentages were recorded $(89.07$ and $67.75 \%)$ of the $2^{\text {nd }}$ and $1^{\text {st }}$ spray. While the least mean of reduction percentages was recorded (48.10 and $31.81 \%)$ of the $3^{\text {rd }}$ and $4^{\text {th }}$ spray. Also, results revealed that the seasonal average reduction percentages were recorded (62.41 and 59.18\%) during first and second season. From the previous results found that the pest spray program effect on Jassid were $2^{\text {nd }}$ and $3^{\text {rd }}$ in $2008 \& 3^{\text {rd }}$ and $1^{\text {st }}$ in 2009 season.

\section{-Nezara veridula:}

Results in Tables (2 and 3) cleared that green bugs, $N$. veridula insect were influenced by the tested programs in comparable with untreated cotton area. The mean of reduction percentages in this pest due to the tested programs were different. The highest mean of reduction percentages were recorded $(100.00,92.15,91.84$ and $83.27 \%)$ of $2^{\text {nd }}, 3^{\text {rd }}$ and $4^{\text {th }}$ and followed by $1^{\mathrm{st}}$ spray in 2008 season, but the highest mean of reduction percentages were recorded $(94.85,94.11,85.90$ and $85.76 \%)$ of the $4^{\text {th }}, 3^{\text {rd }}, 2^{\text {nd }}$ and $1^{\text {st }}$ spray in 2009 . The seasonal mean numbers were recorded (1.48 and 3.33 individuals) in the two seasons, respectively compared with (7.41 and 7.93 individuals) in untreated area. Results revealed that the seasonal average reduction percentages were recorded $(91.82$ and $90.13 \%)$ in the two seasons, respectively.

\section{-Tetranychus sp.}

Results in Tables (2 and 3) showed that Tetranychus sp. numbers were influenced by the test spray programs in comparable with untreated cotton area. The reduction percentages in this pest due to the tested sprays were different: The highest mean of reduction percentages were recorded $(100.00$ and $98.83 \%)$ of the $1^{\text {st }}$ and $2^{\text {nd }}$ spray program in 2008 season. While the lowest mean of reduction percentages were recorded $(61.17 \%)$ of the 3rd spray program .In 2009 season, The highest mean of reduction percentages were recorded $(60.60$ and $52.61 \%)$ of the $4^{\text {th }}$ and $1^{\text {st }}$ spray. While the least mean of reduction percentages was recorded (44.20 and $35.26 \%$ ) of the $2^{\text {nd }}$ and $4^{\text {th }}$ spray during 2009 season. Results revealed that the seasonal average reduction percentages were recorded (84.42 and $48.17 \%$ ) during first and second season.

Table 2: Sid effect of some chemical compounds on insect populations in cotton fields, Sharkia Governorate, 2008 season.

\begin{tabular}{|c|c|c|c|c|c|c|c|c|c|c|c|c|c|c|c|c|c|c|c|c|c|c|c|c|c|}
\hline \multirow{4}{*}{ 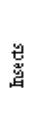 } & \multirow{4}{*}{ 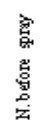 } & \multicolumn{22}{|c|}{ Wromber of insect $/ 75$ cotton plarts } & \multirow{4}{*}{ 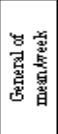 } & \multirow{4}{*}{ 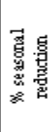 } \\
\hline & & \multicolumn{5}{|c|}{$1^{2}$ spray } & \multicolumn{7}{|c|}{$2^{\text {ad }}$ spray } & \multicolumn{5}{|c|}{$3^{\text {td }}$ spray } & \multicolumn{5}{|c|}{$4^{\text {th spray }}$} & & \\
\hline & & \multicolumn{2}{|c|}{$1^{2 x}$ we ek } & \multicolumn{3}{|c|}{$2^{\text {rof }}$ we ek } & \multicolumn{2}{|c|}{$1^{x}$ we ek } & \multicolumn{2}{|c|}{$2^{\text {rof }}$ we ek } & \multicolumn{3}{|c|}{$3^{\text {rs }}$ week } & \multicolumn{2}{|c|}{$1^{x}$ we ek } & \multicolumn{3}{|c|}{$2^{\text {rof }}$ week } & \multicolumn{2}{|c|}{$1^{x}$ we ek } & \multicolumn{3}{|c|}{$2^{\text {rd }}$ we ek } & & \\
\hline & & w & R.\% & $\mathrm{s}$ & R. $\%$ & Mas & st & $\mathbf{R} . \%$ & w & R. $\%$ & s & R. $\%_{0}$ & Mosm & $x$ & R. $\%$ & w & R. $\%$ & Masm & $\mathrm{s}$ & R. $\%$ & w & R. $\%_{4}$ & Mosm & & \\
\hline \multirow{2}{*}{ 咆 } & 933 & +0 & 43.62 & 333 & 6918 & 58.9 & 20 & 8s 4 & 30 & 53.87 & 0.0 & 100 & 886 & 233 & 54.47 & +0 & 6586 & 6017 & +0 & 4815 & 10 & $4+.65$ & $+6,+0$ & 285 & $a .+1$ \\
\hline & 10.33 & 30 & & 120 & & & 150 & & 120 & & 333 & & & 1.67 & & 2.67 & & & 30 & & 20 & & & 607 & \\
\hline \multirow{2}{*}{ 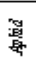 } & 15.0 & 50 & $35 \pi$ & 0.0 & 100 & 83.8 & 0.0 & 100 & 0.0 & 100 & 000 & 100 & 100 & 90 & 790.64 & 30 & 28.32 & $83: 9$ & s.0 & 5113 & 30 & 3708 & $\$+11$ & 2.38 & B.95 \\
\hline & 733 & 100 & & 18.67 & & & 15.67 & & 290 & & 23.67 & & & 210 & & 130 & & & 50 & & 233 & & & 1537 & \\
\hline \multirow{2}{*}{ 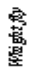 } & 15.0 & 7.67 & 7239 & $1+33$ & 9857 & 85.18 & 260 & 1999 & 360 & 614 & 11.67 & $\pi 99$ & 32.74 & 280 & +8.03 & 90 & $\sin 0$ & $6+02$ & 90 & 19004 & 333 & 32.34 & & 1600 & 6.65 \\
\hline & 90 & 16.67 & & +33 & & & 130 & & 2033 & & 250 & & & 3233 & & 270 & & & 6.67 & & 733 & & & 1696 & \\
\hline \multirow{2}{*}{$\begin{array}{l}\text { है } \\
\text { है } \\
\text { है }\end{array}$} & 80 & 10.67 & 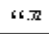 & 10 & $99: 82$ & $83 \pi$ & 0.0 & 100 & 0.0 & 100 & 0.0 & 100 & 100 & 0.67 & $\$ 19$ & 00 & 100 & 9215 & 0.0 & 100 & 1.0 & 85.68 & & 1.48 & $\mathbf{a} \approx 2$ \\
\hline & 10.0 & so & & 70 & & & 533 & & +33 & & 30. & & & 533 & & 11.67 & & & 1433 & & 7.66 & & & $3 .+1$ & \\
\hline \multirow{2}{*}{ 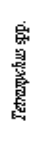 } & 30 & 00 & 100 & 0.0 & 100 & 100 & 10 & 2233 & 30 & 97.64 & 00 & 100 & & 10 & 2233 & 0.0 & 100 & & 20 & 5533 & 00 & 100 & & 0.38 & $\pi s 2$ \\
\hline & 233 & 133 & & 1.0 & & & 10 & & 0.33 & & 0.33 & & & 10 & & 10 & & & 100 & & 1.67 & & & 096 & \\
\hline
\end{tabular}

R.= Reduction $\% \quad \mathrm{~N}=$ Number of larvae 
Table 3: Sid effect of some chemical compounds on insect populations in cotton fields, Sharkia Governorate, 2009 season.

\begin{tabular}{|c|c|c|c|c|c|c|c|c|c|c|c|c|c|c|c|c|c|c|c|c|c|c|c|c|c|}
\hline \multirow{4}{*}{ 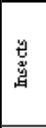 } & \multirow{4}{*}{$\begin{array}{l}\text { 总 } \\
\text { 它 } \\
\text { 总 }\end{array}$} & \multicolumn{22}{|c|}{ Number of insect $/ 75$ cottonp harts } & \multirow{4}{*}{$\begin{array}{l}8 \\
3 \\
3 \\
3\end{array}$} & \multirow{4}{*}{ 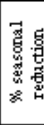 } \\
\hline & & \multicolumn{5}{|c|}{$1^{2}$ spray } & \multicolumn{7}{|c|}{$2^{\text {de }}$ spray } & \multicolumn{5}{|c|}{$3^{\prime d}$ spray } & \multicolumn{5}{|c|}{$4^{\text {th }}$ spray } & & \\
\hline & & \multicolumn{2}{|c|}{$1^{x}$ week } & \multicolumn{3}{|c|}{$2^{\text {rid }}$ we ek } & \multicolumn{2}{|c|}{$1^{x}$ week } & \multicolumn{2}{|c|}{$2^{\text {nd }}$ wreek } & \multicolumn{3}{|c|}{$3^{\text {rd }}$ week } & \multicolumn{2}{|c|}{$1^{x}$ wreek } & \multicolumn{3}{|c|}{$2^{\text {red }}$ week } & \multicolumn{2}{|c|}{$1^{x}$ week } & \multicolumn{3}{|c|}{$2^{\text {nd }}$ week } & & \\
\hline & & Ho. & $\mathrm{R} \%$ & Ho. & $\mathrm{R} \%$ & Me an & No. & $\mathrm{R} \%$ & No. & $\mathrm{R} \%$ & No. & $\mathrm{R} \%$ & Me an & No. & $\mathrm{R} \%$ & No. & $\mathrm{R} \%$ & Me an & No. & $\mathrm{R} \%$ & No. & $\mathrm{R} \%$ & Me $m$ & & \\
\hline \multirow{2}{*}{ 褔 } & $33: 83$ & 1983 & 4138 & 250 & $\$+12$ & 67.75 & 233 & 94.78 & 533 & 86.75 & 350 & 85.67 & $\$ 9.07$ & 325 & 2505 & 2058 & 1114 & $+\$ 10$ & 9.75 & 838 & 17.00 & 9.76 & $31 \mathrm{s1}$ & 956 & 918 \\
\hline & 2116 & 2216 & & 27.84 & & & 2933 & & 2634 & & 16 & & & 23 & & 1517 & & & $13: 84$ & & 1234 & & & 20.67 & \\
\hline \multirow{2}{*}{ 渵 } & 52.67 & 0.0 & 100 & 0.0 & 100 & 100 & 0.0 & 100 & 0.0 & 100 & 0.0 & 100 & 100 & 0.0 & 100 & 46.67 & 2557 & 62.79 & 133.67 & 39.28 & 11333 & 3753 & $38 . \pi$ & 3285 & 7338 \\
\hline & 21 & 2133 & & 3233 & & & 28.67 & & 20.67 & & 37.67 & & & 2333 & & ${ }^{25}$ & & & 38.67 & & 7333 & & & $33.4+$ & \\
\hline \multirow{2}{*}{ 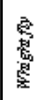 } & 19.67 & 1133 & 460 & 50 & 6.43 & 54.32 & 82 & 20103 & 40 & $18: 3$ & 30 & 1631 & $35 n 2$ & 32 & 2919 & 6 & $\pi 156$ & 50,43 & 38.67 & $26 \pi$ & 47.67 & 33.01 & 2838 & 45.74 & 4219 \\
\hline & 15 & 16 & & 2333 & & & 36.67 & & 25.67 & & 19.67 & & & 30.67 & & 26.67 & & & 38.67 & & 2733 & & & 2719 & \\
\hline \multirow{2}{*}{ 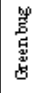 } & 4.67 & 0.0 & 100 & 9.67 & $\pi 152$ & 85.76 & 9.67 & $\pi 305$ & 5.67 & $\$ 137$ & 033 & 9918 & 859 & 133 & $9+32$ & 10 & 9390 & $9+11$ & 20 & 91.46 & 0.33 & 9814 & $9+s s$ & 333 & 9013 \\
\hline & 133 & 4.67 & & 9.67 & & & 12 & & 8.67 & & 13 & & & 6.67 & & 4.67 & & & 6,67 & & 533 & & & 793 & \\
\hline \multirow{2}{*}{ 卷 } & 2.67 & 0.0 & 100 & 0.33 & sin & 52.61 & 0.67 & 4230 & 0.33 & 2304 & 0.67 & 6737 & $4+30$ & 033 & 28.72 & 033 & 41.49 & 3526 & 0.67 & 92.4 & 0.33 & 28.72 & $\varsigma_{0,60}$ & 0.41 & $\$ \$ 17$ \\
\hline & 7.67 & 10 & & 10 & & & 333 & & 0.66 & & 10 & & & 133 & & 0.67 & & & 100 & & 133 & & & 126 & \\
\hline
\end{tabular}

3- Side Effect of certain spray programs against the predator populations in cotton fields:-

The hazardous effect of some conventional insecticides and IGRs on most abundant six predators in cotton fields i.e.; aphid lion, Chrysoperla carnea; beetles, Coccinella spp.; anthocoride bugs Orious spp.; staphylinid beetle. Peaderus alfierii; Scymnus spp. and True spiders, were determined. Tables (4 and 5) the pre- and post treatment numbers and the mean seasonal reduction of the predator's population.

\section{Chrysoperla carnea}

As shown in Tables (4 and 5) showed that the seasonal average numbers recorded weekly was 15.26 individual in 2009 season, followed by 12.22 individual in the second one.

The tested spray programs arranged in descending order against Ch. carnea were as follow $4^{\text {th }}, 3^{\text {rd }}, 1^{\text {st }}$ and $2^{\text {nd }}$ as they recorded $100.00,56.26,53.33$ and $40.76 \%$ mean reduction in 2008 season; $75.40,65.83,46.68$ and $44.63 \%$ in $2^{\text {nd }}, 1^{\text {st }}, 4^{\text {th }}$ and $3^{\text {rd }}$ in 2009 season, respectively. While the seasonal reduction in the two seasons were recorded 62.69 and 58.14 in 2008 and 2009, respectively. Bendict et al. (1986) reported that number of predaceous insects were not significantly affected by treatment by chlordimeform. Also, found decreasing of average seasonal abundance, the beneficial arthropods were Chrysopa spp.. El-Saadany et al. (1999) stated that predator density, Chrysopa carnea [Chrysoperla carnea] were three times more numerous in pheromone treated fields than the corresponding cotton fields treated with conventional insecticides. Hegab (2002) the harmful side effects of three spray programmes (Es-fenvalerate, Es-fenvalerate + profenofos and Es-fenvalerate + profenofos + thiodicarb) on the incidence of flying adults of some predaceous insects such as, Chrysoperla carnea in cotton during 1998 and 1999 seasons. The results obtained indicated that the three tested spray programmes had highly significant adverse effects on the population density of this arthropod species. Recorded 37.67 and $49.18 \%$ in 1998 and 1999 seasons.

\section{Coccinella spp.}


The conventional insecticide and IGR mixture caused the highest reduction in the numbers of the predatory stages of Coccinella spp., attained $100.00 \%$ mean reduction in the $2^{\text {nd }}, 3^{\text {rd }}$ and $4^{\text {th }}$ spay program followed by $76.20 \%$ reduction in the 1 st spray and attained $94.05 \%$ seasonal reduction in 2008 season. In 2009 season the all tested programs caused the highest mean reduction percentage in all tested programs attained $100.00 \%$ and showing highest seasonal reduction percentage attained 100.00 $\%$. Tables (4 and 5). Bendict et al. (1986) reported that number of predaceous insects were not significantly affected by treatment by chlordimeform. Also, found decreasing of average seasonal abundance, the beneficial arthropods were Coccinella spp., El-Saadany et al. (1999) stated that that predator densities Coccinella undecimpunctata, were three times more numerous in pheromone treated fields than the corresponding cotton fields treated with conventional insecticides. Hegab (2002) the harmful side effects of three spray programmes, (Es-fenvalerate, Es-fenvalerate +profenofos and Es-fenvalerate +profenofos +thiodicarb), showed the sensitivity of the considered arthropod species. Coccinella spp. insect showed the lowest reduction percents in their population density exhibiting means of $37.67 \%$ in 1998 season and $50.22 \%$ in 1999 season, respectively.

\section{Orius spp.}

The numbers of these bugs were low during the two cotton seasons of 2008 and 2009 recording 0.41 and 1.70 individual /week, in control treatment, respectively. Data in Tables (4 and 5) showed that Orious spp. in both experimental seasons were highly affected with all tested programs which resulted in mean reductions of 93.24, 95.83, 100.00 and $73.43 \%$ in 2008 seasons of all the tested programs, respectively;100.00,100.00, 53.06 and $49.83 \%$ in 2009 season and caused 90.63 and $75.34 \%$ highly seasonal reduction in two seasons, respectively. Bendict et al. (1986) reported that number of predaceous insects were not significantly affected by chlordimeform and caused decreasing of average seasonal abundance of Orius spp.. El-Saadany et al. (1999) stated that Orius spp. were decreased population numbers in cotton treated by insecticides. Hegab (2002) stated that the three tested spray programmes had highly significant adverse effects on the population density of Orius spp.recorded 52.95 and $40.35 \%$ reduction during two seasons, respect.

\section{Paederus alfierii}

This predator was found in low numbers in both experimental seasons 0.18 and 0.00 individual /week in 2008 and 2009 seasons, respectively. The all tested program arranged in descending order against $P$. alfierii were as follow, $2^{\text {nd }}, 3^{\text {rd }} 4^{\text {th }}$ and $1^{\text {st }}$ mean reduction as they recorded $100.00,100.00,100.00$ and $98.16 \%$ mean reduction in 2008 season; $100.00 \%$ mean reduction in 2009 season, respectively The seasonal average reduction percentage were recorded 99.54 and $100.00 \%$ seasonal reduction in the two seasons, respect. El-Saadany et al. (1999) stated that that predator densities, Paederus alfierii were three times more numerous in pheromone treated fields than cotton fields treatment with conventional insecticide. Hegab (2002) found the effect of three spray programmes on Paederus alfieri in cotton 1998 and 1999 seasons. The results obtained indicated that the three tested spray programmes had highly significant adverse effects on the population density of P. alfieri. was recorded 66.36 and 56.83 in 1998 and 1999 seasons.

\section{Scymnus spp.}

Data in Tables (4 and 5) showed that 3rd, 2nd and 1st programs caused $100.00,95.83$ and $93.24 \%$ highly mean reduction followed $74.45 \%$ reduction in the 1st spray in 2008 season;100.00, 95.47, 83.03 and 58.69 \% in 2009 season, respectively and causing 91.89 and $84.30 \%$ highly seasonal reduction in the two 
seasons, respectively. Bendict et al. (1986) reported that number of predaceous insects wre not significantly affected by treatment by chlordimeform and decreasing Scymnus spp. population numbers. Hegab (2002) results obtained indicated that the three tested spray programmes had highly significant adverse effects on Scymnus spp. recorded 58.68 and $47.36 \%$ reduction in the two seasons.

\section{True spiders}

The seasonal mean numbers of the true spiders recorded 13.11 and 14.37 spiders in untreated area in 2008 and 2009 seasons, respectively.

Data in Tables (4 and 5) revealed that the harmful effect of the used insecticides on true spiders in descending order is as follow $; 4^{\text {th }}, 3^{\text {rd }}, 2^{\text {nd }}$ and $1^{\text {st }}$ program, recording 100.00 , $94.89,89.25$ and $70.23 \%$ mean reductions, in $2008 ; 2^{\text {nd }}, 3^{\text {rd }}, 4^{\text {th }}$ and $1^{\text {st }}$ programs, recording $79.03,64.27,26.06$ and $24.67 \%$ mean reduction in 2009 season. Also, results revealed that the all tested programs caused 88.59 and $48.51 \%$ seasonal mean reduction in the two seasons, respectively.

The present results are in fully agreement with those obtained by many authors such as; Bendict et al. (1986) reported that number of spiders were not significantly affected by treatment by chlordimeform. Murray and Lioyd (1997); Abo-Elhagag (1998); Laba et al. (1998) in Indonesia, found that, several insecticides namely organochlorine, organophosphate, carbamate and pyrethroid insecticides and formamidine acaricides, also had a negative effect on natural enemies. Aioub et al. (2002), who reported that insecticides applications in cotton fields against different pests had an adverse and highly significant effect on numbers of spider Nada (1990), found that insecticides slightly reduced the populations of spiders associated with cotton pests and the differences between their numbers in treated and untreated fields were not significant. Hegab (2002) results indicated that the three tested spray programmes had highly significant adverse effects on the population density of true spiders recorded 44.47 and $66.17 \%$ reduction. Yousif-Khalil et al. (2008) found that chlorpyrifos caused the highest degree of $\%$ reduction for all investigated predators, followed by spinosad and methoxyfenozide, and recorded general reduction of 77.44, 49.36 and $42.20 \%$ in 2004 season, and 70.71,49.22 and 35.05\% in 2005 cotton season, respectively. Otto et al. (2009) reported that pesticides play a double role: Providing a barrier for chemical spray drift and as a refuge for beneficial arthropods such as pollinators and predators. Pesticide can negatively affect the beneficial arthropods.

Table 4: Side effect of different control programs on predacious populations in cotton fields, Sharkia Governorate, 2008 season

\begin{tabular}{|c|c|c|c|c|c|c|c|c|c|c|c|c|c|c|c|c|c|c|c|c|c|c|c|c|c|}
\hline \multirow{4}{*}{ 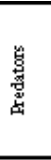 } & \multirow{4}{*}{ 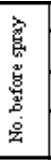 } & \multicolumn{22}{|c|}{ No. of pre dator s $/ 100$ cotton plarts } & \multirow{4}{*}{ 卷 } & \multirow{4}{*}{ 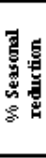 } \\
\hline & & \multicolumn{5}{|c|}{$1^{2}$ spray } & \multicolumn{7}{|c|}{$\frac{2^{\infty}}{\text { spray }}$} & \multicolumn{5}{|c|}{$3^{\text {Id }}$ pray } & \multicolumn{5}{|c|}{$\frac{4^{\text {th }} \text { spray }}{4}$} & & \\
\hline & & \multicolumn{2}{|c|}{$1^{\mathbf{x}}$ week } & \multicolumn{2}{|c|}{$2^{\text {wa }}$ we ek } & \multirow[t]{2}{*}{ Me $m$} & \multicolumn{2}{|c|}{$1^{\mathbf{x}}$ week } & \multicolumn{2}{|c|}{$2^{\text {ad }}$ week } & \multicolumn{2}{|c|}{$3^{\text {Id }}$ we ek } & \multirow[t]{2}{*}{ Mesm } & \multicolumn{2}{|c|}{$1^{2}$ week } & \multicolumn{2}{|c|}{$2^{\mathrm{a}}$ week } & \multirow[t]{2}{*}{ Me $m$} & \multicolumn{2}{|c|}{$1^{\text {In }}$ week } & \multicolumn{2}{|c|}{$2^{\text {ad }}$ week } & \multirow[t]{2}{*}{ Me an } & & \\
\hline & & No. & $\begin{array}{l}\mathrm{R} . \\
\mathrm{S}_{0}\end{array}$ & No. & $\begin{array}{l}R . \\
\psi_{0}\end{array}$ & & No. & $\begin{array}{l}R . \\
\% \\
\end{array}$ & No. & $\begin{array}{l}R . \\
\text { R. } \\
\end{array}$ & No. & $\begin{array}{l}\text { R. } \\
\%\end{array}$ & & No. & $\begin{array}{l}\text { R. } \\
\%\end{array}$ & \begin{tabular}{|l|} 
Ho. \\
\end{tabular} & $\begin{array}{l}\mathrm{R} . \\
\%\end{array}$ & & Ho. & $\begin{array}{l}\mathrm{R} . \\
\%\end{array}$ & No. & $\begin{array}{l}R . \\
\%\end{array}$ & & & \\
\hline \multirow{2}{*}{ 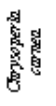 } & 9.6 & 3 & 937 & 4.67 & 5707 & $53 . n$ & 1533 & 5533 & 11 & 2701 & 10 & 3995 & 40.76 & 7 & 88.42 & 3.67 & 2409 & 5626 & 0.0 & 100 & 0.0 & 100 & 100 & 7.67 & 9.69 \\
\hline & 16 & 16.67 & & 18 & & & 1633 & & $1+33$ & & 1033 & & & 10.67 & & 8 & & & 4.67 & & 11 & & & 1232 & \\
\hline \multirow{2}{*}{ 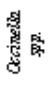 } & 1633 & 3.67 & $n .+0$ & 00 & 100 & 762 & 00 & 100 & 0.0 & 100 & 0.0 & 100 & 100 & 00 & 100 & 0.0 & 100 & 100 & 0.0 & 100 & 0.0 & 100 & 100 & 7.67 & 98,07 \\
\hline & 25.67 & $v 33$ & & 22.67 & & & 21.67 & & 14 & & 1133 & & & 15 & & 6.67 & & & 3 & & 10 & & & $13 .+1$ & \\
\hline \multirow{2}{*}{ 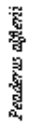 } & 18 & 1.6 & $x_{31}$ & 00 & 100 & 9616 & 00 & 100 & 0.0 & 100 & 0.0 & 100 & 100 & 0.0 & 100 & 0.0 & 100 & 100 & 0.0 & 100 & 0.0 & 100 & 100 & 018 & 9954 \\
\hline & 2 & 3 & & 633 & & & 533 & & 6.67 & & + & & & 2.67 & & 233 & & & 4.67 & & 133 & & & 437 & \\
\hline \multirow{2}{*}{$\mathrm{E}_{\mathrm{B}}$} & 19 & 633 & 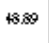 & 00 & 100 & 74.45 & 00 & 100 & +33 & 91,40 & 0.0 & 100 & 9714 & 0.00 & 100 & 133 & 9195 & 9598 & 0.0 & 100 & 0.0 & 100 & 100 & 133 & $g_{R}$ \\
\hline & 7.67 & 5 & & 11.67 & & & 1833 & & 2033 & & 1533 & & & 12.67 & & 6.67 & & & 14.67 & & 1033 & & & 12.78 & \\
\hline \multirow{2}{*}{ हैं } & 8 & 2 & $\approx .47$ & 00 & 100 & 9324 & 00 & 100 & 0.0 & 100 & 10 & 875 & 9583 & 00 & 100 & 00 & 100 & 100 & 0.6 & 46.68 & on & 100 & 73.3 & 0.41 & 90.63 \\
\hline & +33 & 80 & & 333 & & & +33 & & 733 & & +33 & & & 00 & & 00 & & & 0.67 & & 0.67 & & & 2.7 & \\
\hline \multirow{2}{*}{ 葛意 } & 21 & 6.67 & $\omega . \pi$ & 50 & 73.35 & 7013 & 6.7 & 7686 & 20 & 9090 & 0.0 & 100 & 9935 & 00 & 100 & 10 & $\approx \pi$ & 9499 & 0.0 & 100 & 0.0 & 100 & 100 & 237 & $\approx 8.59$ \\
\hline & $1+3$ & 13.67 & & 13 & & & 19.67 & & 150 & & 1633 & & & 80 & & 6.67 & & & 130 & & 12.67 & & & 1311 & \\
\hline
\end{tabular}


Table 5: Side effect of different control programs on predacious populations in cotton fields, Sharkia Governorate, 2009 season.

\begin{tabular}{|c|c|c|c|c|c|c|c|c|c|c|c|c|c|c|c|c|c|c|c|c|c|c|c|c|c|}
\hline \multirow{4}{*}{ 兽 } & \multirow{4}{*}{ 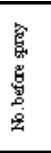 } & \multicolumn{22}{|c|}{ No. of predators $/ 100$ cotton plarts } & \multirow{4}{*}{ 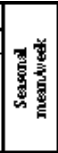 } & \multirow{4}{*}{ 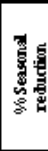 } \\
\hline & & \multicolumn{5}{|c|}{ 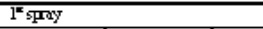 } & \multicolumn{7}{|c|}{$2^{\text {ad }}$ spray } & \multicolumn{5}{|c|}{$3^{\text {Id }}$ spray } & \multicolumn{5}{|c|}{$4^{n} \sin y$} & & \\
\hline & & \multicolumn{2}{|c|}{1 "'reetk } & \multicolumn{2}{|c|}{$2^{\text {red }}$ reekk } & \multirow{2}{*}{ Meam } & \multicolumn{2}{|c|}{1 I reek } & \multicolumn{2}{|c|}{ 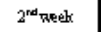 } & \multicolumn{2}{|c|}{$3^{n+1}$ reek } & \multirow{2}{*}{ Meam } & \multicolumn{2}{|c|}{1 "wweek } & \multicolumn{2}{|c|}{$2^{\text {rd }}$ reeek } & \multirow{2}{*}{ Meam } & \multicolumn{2}{|c|}{$1^{*}$ week } & \multicolumn{2}{|c|}{$z^{s}$ weets } & \multirow{2}{*}{ Mream } & & \\
\hline & & No. & $\begin{array}{l}\text { R. } \\
\%\end{array}$ & No. & $\begin{array}{l}\mathrm{R} . \\
\%\end{array}$ & & No. & $\begin{array}{l}\mathrm{R} . \\
\%\end{array}$ & No. & $\begin{array}{l}\text { R. } \\
\%\end{array}$ & No. & $\begin{array}{l}\text { R. } \\
\%_{0}\end{array}$ & & No. & $\begin{array}{l}\text { R. } \\
\%\end{array}$ & No. & $\begin{array}{l}\mathrm{R} . \\
\mathrm{s}_{0}\end{array}$ & & No. & $\begin{array}{l}\text { R. } \\
\%\end{array}$ & No. & $\begin{array}{l}\text { R. } \\
\text { R. }\end{array}$ & & & \\
\hline \multirow{2}{*}{ 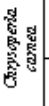 } & 180 & 0.0 & 100 & 14 & 31.66 & 6.35 & 333 & 7896 & 23.67 & 2211 & 19.67 & 76,02 & 75.4 & 18.0 & 5257 & 933 & 36.69 & $4+.63$ & 18.67 & 30.79 & 27.67 & $\$ 956$ & 46.68 & 1493 & 5814 \\
\hline & 1933 & 19.7 & & 220. & & & $17 \pi$ & & 15.67 & & 120 & & & 12.67 & & 733 & & & 1533 & & 15.67 & & & บ26 & \\
\hline \multirow{2}{*}{ 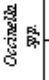 } & 1433 & 0.0 & 100 & on & 1000 & 10000 & 0.0 & 100 & of & 100.0 & 0.0 & 1000 & 1000 & 00 & 1000 & 0.0 & 1000 & 1000 & 00 & 1000 & on & 1000 & 1000 & 0.0 & 10000 \\
\hline & 2567 & 300 & & 1733 & & & 250 & & 13.67 & & 160 & & & 18.67 & & 833 & & & 4.67 & & 300 & & & \begin{tabular}{|l|}
18 \\
\end{tabular} & \\
\hline \multirow{2}{*}{ 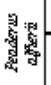 } & 20 & 0.0 & 100 & 00 & 100 & 1000 & 0.0 & 100 & 00 & 100 & 00 & 100 & 100 & 00 & 100 & 0.0 & 100 & 100 & 00 & 100 & 0.0 & 100 & 100 & 0.0 & 100 \\
\hline & 9.67 & 4.67 & & +0 & & & 60 & & so & & 30 & & & 433 & & 20 & & & 5.67 & & 12.67 & & & 526 & \\
\hline \multirow{2}{*}{ 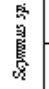 } & 1633 & 0.0 & 100 & 0.0 & 100 & 1000 & 333 & $\$ 9.3$ & 00 & 100 & 0.67 & 9699 & 95.47 & 733 & $\pi 16$ & 3 & $\approx \infty 8$ & 83.03 & +0 & 82.67 & $1+36$ & 34.72 & 58.69 & 3.63 & $\$ 30$ \\
\hline & 9.67 & 9.67 & & 10.67 & & & 18.67 & & 1433 & & 12.67 & & & 19 & & 16 & & & 13.67 & & 13 & & & $1+19$ & \\
\hline \multirow{2}{*}{ हैं } & 8.67 & 0.0 & 100 & of & 100 & 1000 & 00 & 100 & 0.0 & 100 & 0.0 & 100 & 100 & 20 & 5703 & 20 & +908 & 5306 & 533 & 46.76 & 60 & 4983 & 4829 & 1.70 & 7234 \\
\hline & 4.33 & 033 & & 30 & & & 637 & & 20 & & 3.67 & & & +0 & & 0.67 & & & 50 & & 20 & & & 30 & \\
\hline \multirow{2}{*}{ 总吠 } & 2767 & 23.7 & 22.54 & 2533 & 26.79 & 4.67 & 500 & $\$ 0.1$ & 833 & 69.75 & 4.67 & 86.76 & 790.13 & 500 & $\$ 239$ & 1633 & +614 & $4+23$ & 13 & 40.55 & 25.67 & 1156 & 2606 & 1411 & 4851 \\
\hline & 1430 & 1433 & & 13.67 & & & 1333 & & 140 & & 1733 & & & 14.67 & & 15.67 & & & 1133 & & 150 & & & 1437 & \\
\hline
\end{tabular}

\section{3- The relationship between some cotton pests and the predacious arthropods in} cotton fields:

Results in Tables (6 and 7) indicated the influence of Scymnus, Coccinella spp. Scymnus spp., Orious spp. and true spiders were insignificant in the two seasons and ranged between positive \& negative relationship. On the other hand, results indicate that the all predators affect on aphids with 29.73 and $32.54 \%$ in the two seasons.

Table 6: Simple correlation and multiple regression coefficient between some predacious predators associated with some cotton pests in Sharkia Governorate during 2008 cotton season 


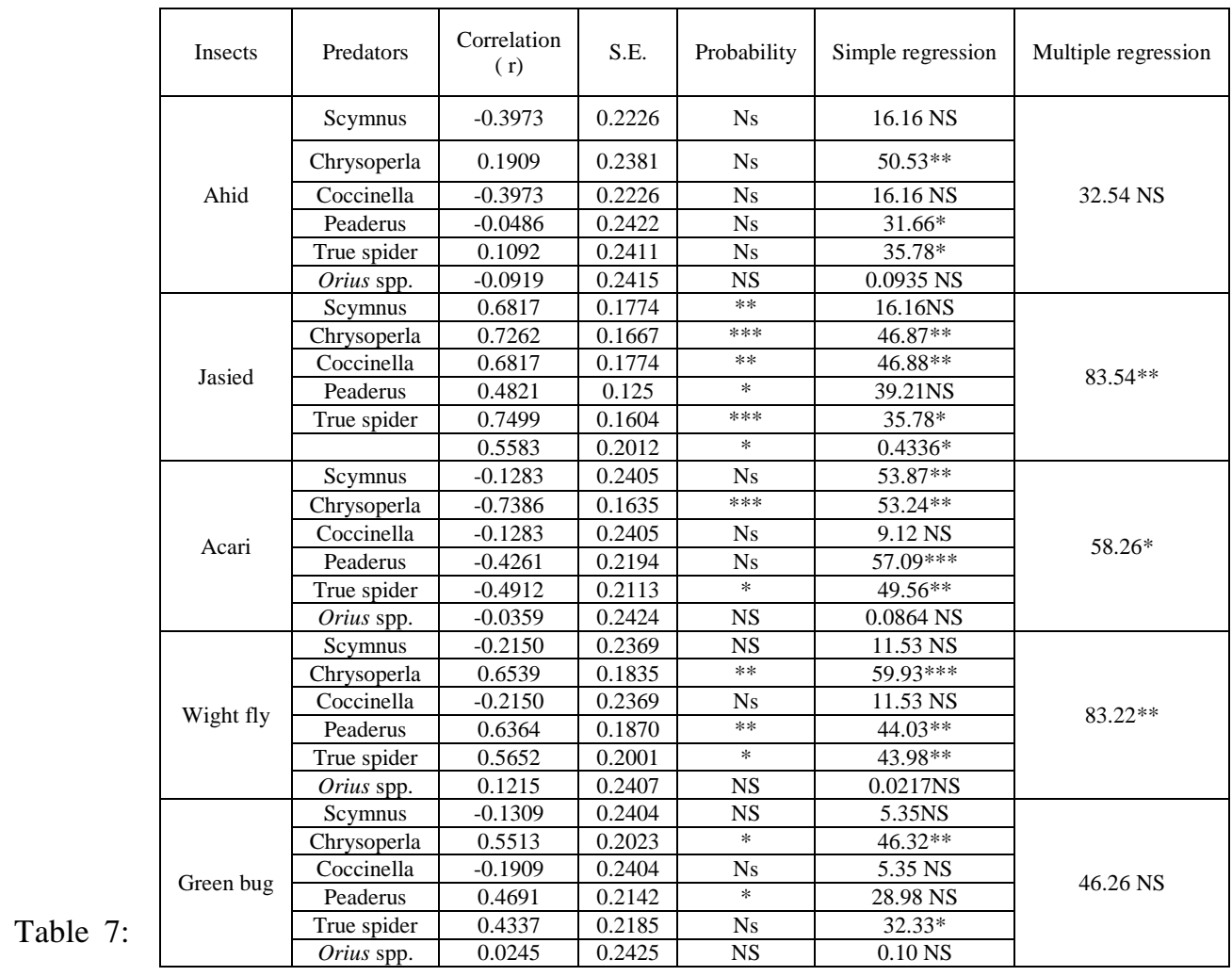

Simple

correlation and multiple regression coefficient between some predacious predators associated with some cotton pests in Sharkia Governorate during 2009 cotton season.

\begin{tabular}{|c|c|c|c|c|c|c|}
\hline Insects & Predators & $\begin{array}{c}\text { Correlation } \\
\text { (r) }\end{array}$ & S.E. & Probability & Simple regression & Multiple regression \\
\hline \multirow{6}{*}{ Ahid } & Scymnus & 0.4307 & 0.2127 & $\mathrm{~ns}$ & $21.09 \mathrm{~ns}$ & \multirow{6}{*}{$29.73 \mathrm{Ns}$} \\
\hline & Chrysoperla & 0.2065 & 0.2306 & Ns & $6.69 \mathrm{~ns}$ & \\
\hline & Coccinella & -0.0560 & 0.2353 & Ns & $0.32 \mathrm{~ns}$ & \\
\hline & Peaderus & 0.3506 & 0.2207 & Ns & $1661 \mathrm{~ns}$ & \\
\hline & True spider & 0.1679 & 0.2324 & Ns & $5.29 \mathrm{~ns}$ & \\
\hline & Orious spp. & 0.3619 & 0.2197 & $\mathrm{~ns}$ & $0.1374 \mathrm{~ns}$ & \\
\hline \multirow{6}{*}{ Jasied } & Scymnus & 0.4365 & 0.2121 & Ns & $42.62 * *$ & \multirow{6}{*}{$61.88^{*}$} \\
\hline & Chrysoperla & 0.4365 & 0.2121 & Ns & $23.09 \mathrm{~ns}$ & \\
\hline & Coccinella & 0.6741 & 0.1741 & $* *$ & $78.77 * * *$ & \\
\hline & Peaderus & 0.1187 & 0.2340 & Ns & $10.79 \mathrm{~ns}$ & \\
\hline & True spider & 0.3089 & 0.2241 & Ns & $12.40 \mathrm{~ns}$ & \\
\hline & Orious spp. & 0.2115 & 0.2304 & Ns & $0.1701 \mathrm{~ns}$ & \\
\hline \multirow{6}{*}{ Acari } & Scymnus & -0.5309 & 0.1997 & $* *$ & 53.87 ** & \multirow{6}{*}{$52.46 \mathrm{Ns}$} \\
\hline & Chrysoperla & -0.6437 & 0.1804 & $* *$ & $52.24 * *$ & \\
\hline & Coccinella & -0.1399 & 0.2334 & Ns & $9.12 \mathrm{~ns}$ & \\
\hline & Peaderus & -0.6249 & 0.1840 & $* *$ & $57.09 * * *$ & \\
\hline & True spider & -0.4306 & 0.1997 & $*$ & $49.56 * *$ & \\
\hline & Orious spp. & -0.3509 & 0.2217 & Ns & $0.1840 \mathrm{Ns}$ & \\
\hline \multirow{6}{*}{ Wight fly } & Scymnus & 0.5301 & 0.1999 & $*$ & $33.48^{*}$ & \multirow{6}{*}{$35.57 \mathrm{Ns}$} \\
\hline & Chrysoperla & 0.2535 & 0.289 & $\mathrm{Ns}$ & $11.69 \mathrm{Ns}$ & \\
\hline & Coccinella & -0.0936 & 0.2347 & Ns & $2.44 \mathrm{Ns}$ & \\
\hline & Peaderus & 0.4225 & 0.2136 & Ns & $33.49^{*}$ & \\
\hline & True spider & 0.1826 & 0.2317 & Ns & $28.46 \mathrm{Ns}$ & \\
\hline & Orious spp. & 0.2176 & .02301 & Ns & $0.1626 \mathrm{Ns}$ & \\
\hline \multirow{6}{*}{ Green bug } & Scymnus & 0.5368 & 0.1994 & $*$ & $44.05^{* *}$ & \multirow{6}{*}{$49.14 \mathrm{Ns}$} \\
\hline & Chrysoperla & 0.5368 & 0.1988 & $*$ & 83.42 *** & \\
\hline & Coccinella & -0.1344 & 0.2336 & Ns & $22.89 \mathrm{~ns}$ & \\
\hline & Peaderus & 0.5815 & 0.1917 & $* *$ & $56.09 * * *$ & \\
\hline & True spider & 0.3832 & 0.2177 & Ns & $36.55^{*}$ & \\
\hline & Orious spp. & 0.3075 & 0.2242 & Ns & $0.3399 *$ & \\
\hline
\end{tabular}


Data in the same tables cleared that the relationship between jasied and insect predators mentioned were positive and ranged between significant $\&$ insignificant in the two seasons. Data indicate that the influence of five population predators were significant effect $\&$ caused 61.98 and $83.54 \%$ mutable regression in the $1^{\text {st }}$ and $2^{\text {nd }}$ seasons.

Present data in the same table indicate the relationship between B. tabaci and all population predators were positive and insignificant of all predators, except Coccinella spp. had a negative relationship and significant relationship with Scymnus spp. in the 1st season, while it were (negative \& positive) and (significant and insignificant relationship) in the $2^{\text {nd }}$ one. Results cleared that the influence of five population predators studied were 35.57 and $83.22 \%$ multiple regression values and (insignificant and highly significant) in the 1 st and 2nd seasons, respect.

\section{REFERENCES}

Abdalla, E. F. (1991): Effect of sowing date and certain chemical control programs against the cotton bollworms, Pectinophora gossypiella (Saund.) and Earias insulana (Boisd.). Bull. Enomol. Soc., Egypt, Economic series, 19:157-165.

Abou-Elhagag, G. H. (1998). Effect of spraying cotton plants during the early season against cotton aphid on cotton pest, natural enemies and some crop characters in southern Egypt., Assiut Journal of Agricultural Sciences, 29 (4): 91-100.

Aioub, A. A. A.; E.A. Gomaa; W. M. H. Desuky and A. A. A. Zaki (2002). Management of sap sucking insect population on cotton plants by imdacloprid application and NPK fertilization. Zagazig J.Agric. Res., 29 (1): 269-289.

Al-Shannaf, M. H. A. (2002): Studies on some cotton pests. Ph.D. Thesis.Fac.Agric. Zagaz

Bendict, J. H.; M. H.Walmsley; J. C. Sergers; and M. F.Treacy (1986). Yield enhancement and insect supression with chlordimeform (Fundal) on dryland cotton. J. Econ. Entomol., 79:238-242.

Dhawan A. K.; G. S. Simwat and A. S. Sidhu (1990): Management of bollworms on cotton with synthetic pyrethroids. J. of insect Science, 3 (2):158-161.

El-Saadany G. B.; R. S. M. El-Fateh; Z. H. A. Hamida and M. A. Romeilah (1999). The triangle relationship between key pests related biological agents and specific chemicals as factors governing the cotton IPM program. Egypt. J. Agric. Res., 77 (2): 559-574.

Hegab, M. E. M. (2002): Studies on bollworms infesting cotton in Sharkia Governorate, Egypt .M. Sc. Thesis, Zagazig Univ., 207 pp.

Henderson, C. F. and E.W. Telton (1955). Tests with acaricides against the brown wheat mite. J. Econ. Entomol., 48: 157-161.

Horowitz A.R. and I. Ishaaya (2004): Insect pest management: field and protected crops.

Ishaaya I.; Kontsedalov S. and Horowitz A.R .(2002): Emamectin, a novel insecticide for controlling field crop pests. Pest Manag Sci., 58(11):1091-5.

Khattak, M. K.; S. D. Khan; K. Liaqatullah and G. S. Shah (2004): Efficacy of various insecticides on the damage and incidence of cotton bollworms and beneficial fauna. Pakistan Entomologist, 26 (1): 19-23.

Knight, A. I. (2000): Tebufenozide targeted against codlig moth (Lepidoptera:Tortricidae) adults,eggs and larvae.J. Econ.Entomol.93: 760-767.

Laba, W.; D. Kilin and D. Soetopo (1998). The impacts of insecticides use in pest control. J. Pemelition Pengembangan Peratnan , 17 (3): 99-107.

Murray, D. A. H. and R. J. Lioyd (1997). The effect of spinosad (Tracer) on arthropod pests and beneficial population in Australian cotton. Proceeding of Beltwide Cotton Conferences, New Orleans, LA. U.S.A., Januray, 2: 6-10.

Nada, M. A. (1990). Control of certain pests infesting cotton plants in Sharkia Region. Ph.D. Thesis Fac. Agric., Zagazig Univ.,: 203pp.

Naranjo, S. and D. H. Akey (2005): Conservation of natural enemies in cotton: comparative selectivity of acetamiprid in the management of Bemisia tabaci. 70 :Pest Manag Sci. 61(6):555-66. 
Otoidobiga L. C.; C. Vincent and R.K. Stewart (2003): Susceptibility of field populations of adult Bemisia tabaci Gennadius (Homoptera: Aleyrodidae) and Eretmocerus sp. (Hymenoptera: Aphelinidae) to cotton insecticides in Burkina Faso (West Africa). Pest Manag Sci. 59(1):97-106.

Otto, S.; L. Lazzaro; A. Finizio and G. Zanin (2009): Estimating ecotoxicological effects of pesticide drift on nontarget arthropods in field hedgerows. Environ Toxicol Chem.28 (4):853-63.

Sarag, D. G. and U. S. Satpute (1988): Efficacy of some synthetic insecticides and Bacillus thuringiensis var. Kenyae against bollworms of cotton. PKV, Research J., 12 (2): 119122.

Sidhu, A. S.; A. K. Dhawan and G. S. Simwat (1986): Testing of fenvalerate and permethrin for the control of pink bollworm in the Punjab. Pesticides, 20 (1): 17-18.

Simwat, G.S. and A.K. Dhawan (1992): Efficacy of diflubenzuron and in combination with insecticides for control of bollworms on different varieties of upland cotton Gossypium hirsutum). Indian J. of Agrc. Sci., 62 (6):424-426.

Watson, W. M.; Amira M. Rashad and, Nagwa M. Hussien (1986): Potencies of certain insecticides against the pink bollworm, Pectinophora gossypiella (Saund.) as influenced by chemical control program in Egypt. Bull. Entomol. Soci. Egypt, Economic Series, (15):79-86.

Yousif-Khalil, S.I.; S. A. A. Raslan; Ola I. Hegab and Omnia S. Abd-Elsttar (2008): Efficiency of spinosad and runner against pink bollworm and predators population on cotton fields .Zagazig J. Agric. Res., 35 (2): 407-422.

\footnotetext{
ARABIC SUMMARY تاثير تتابع الرش ضد ديدان اللوز فى القطن والتاثيرات الجانبية على الافات الثاقبة الماصه و المفترسات الحثرية 